NATIONAL COMPETITIVENESS, KNOWLEDGE AND FOREIGN INVESTMENT

\author{
Manuel Portugal Ferreira \\ Center of Research in International Business \& Strategy \\ Polytechnic Institute of Leiria, Portugal \\ portugal@estg.ipleiria.pt \\ Fernando A. Ribeiro Serra, Dr. \\ University of Southern Santa Catarina (UNISUL), Brasil \\ fernando.serra@unisul.br \\ Carlos Duarte, Dr. \\ School of Management of Tomar \\ Polytechnic Institute of Tomar, Portugal \\ cduarte@ipt.pt \\ Tânia Marques \\ School of Technology and Management \\ Polytechnic Institute of Leiria, Portugal \\ taniamarques@estg.ipleiria.pt
}

\title{
ABSTRACT
}

National competitiveness has been the subject of attention in academic and entrepeneurial forums as well as a matter of concern for governmental, industrial, and education-form policy makers. In this paper, we discuss the conditions for national competitiveness in terms of the innovation systems, foreign direct investment, technological capabilities, innovation and institutions. Innovative countries benefit from localized learning that may be exploited within and across borders. Participation in research networks is not the sole avenue to development when in presence of an attitude that promotes learning and the adoption of the most recent technologies.

Key-words: Technological Development. National Competitiveness. Innovation. Innovation systems 


\section{COMPETITIVIDADE NACIONAL, CONHECIMENTO E INVESTIMENTO ESTRANGEIRO ${ }^{1}$}

\section{RESUMO}

National competitiveness has been the subject of attention in academic and entrepeneurial forums as well as a matter of concern for governmental, industrial, and education-form policy makers. In this paper, we discuss the conditions for national competitiveness in terms of the innovation systems, foreign direct investment, technological capabilities, innovation and institutions. Innovative countries benefit from localized learning that may be exploited within and across borders. Participation in research networks is not the sole avenue to development when in presence of an attitude that promotes learning and the adoption of the most recent technologies.

Key-words: Technological Development. National Competitiveness. Innovation. Innovation systems

\footnotetext{
${ }^{1}$ Redigido em Português de Portugal.
} 


\section{INTRODUCTION}

The competitiveness of national agents relies both on the capacity for domestic innovation and the ability to learn, alongside international agents, the most recent technological developments-namely the flexibility to fill niches with variable geometry. Issues regarding competitive capacity have long been central in the debate over public policy, entrepreneurial strategy, and even education and research policies.

During the 1990s, enterprises and countries started to awaken to the difficulties imposed by the competition arising from emerging, less-developed economies. The issue seems simple: how enterprises and countries will face the advantages of location as manifested through cheap labor, lower environmental standards, and fewer social security burdens. Given the impact of the international financial-economic crisis, the issue of how to compete is even more relevant.

One of the possibilities of restoring the competitive capacity of countries in an intermediate-developed category specifically entails repairing a large portion of their productive and industrial fabric. Enterprises in these countries can hardly expect to compete with Asian or even Central and South American businesses if they are based solely on traditional productive factors.

Currently, enterprises and countries are competing to take on a central role in the new knowledge economy, in which it is established that the basis for a new model of sustainable competitive advantage lies in knowledge and innovation (Buckley and Casson, 1976; Grant, 1996; Porter, 1998, 2000; Cantwell and Iammarino, 2000; Cantwell, 2001).

Government policies, as well as the entrepreneurial strategies of private agents (i.e. enterprises), play an essential role in the acquisition of new skills. First, industrial policies either promote or discourage the influx of foreign investment. Foreign investment can be of the kind that explores international differences in the costs of production factors, or the kind that contributes to the development of knowledge-in other words, that which results in the influx of innovations and technological skills. Enterprises are also essential for their research and development (R\&D) efforts and their internationalization strategies, especially to the extent that they can choose which markets to internationalize, either to market their products or access new knowledge (Ferreira, 2005; Li, Ferreira and Serra, 2009). 
In this article we analyze competitiveness factors associated with technological policy and institutions that support technological development. This issue takes on greater importance when countries in general promote industrial policies that support the creation of regional clusters or agglomeration. Besides the obvious objectives of wealth and job creation, these clusters are generated in order to be internationally competitive, but in most cases are created without a circumstantial analysis of a nation's competitive advantages (Porter, 1990), either of the allocation and evolution of internal factors or of the markets and the role of government.

The article is structured as follows. First we discuss a few factors of national competitiveness. Next, we examine foreign direct investment, both its type and its benefits. In the third part we present a reflection on technological pathways, the potential for learning, and the role of institutions. Finally, we focus on a very specific aspect, the effect of imitation as framed in entrepreneurial strategy. We have thus structured the sections so as to discuss some of the competitiveness factors from two distinct perspectives: at the level of public policy, and at the level of businesses and private agents.

We conclude that a technological policy that supports national development should focus on the terms of exchange in international trade, investment flows, and the foreign and domestic institutions that support R\&D and education. In sum, we suggest that the technological policy in a country that has intermediate development need not rely on R\&D in all activity sectors, but rather that alterations in the national technological path can be achieved through the capture of certain types of foreign investment and support for the internationalization of enterprises which contribute to increasing the national endowment of knowledge.

\section{NATIONAL COMPETITIVENESS}

\subsection{THE PROBLEM}

By and large, public agents are concerned about national competitiveness. This is not a new concern, despite the fact that it has been newly reinforced by the globalization of markets and products, technological changes, shortened distances, market liberalization, and competition for knowledge. It is nevertheless a salient concern, even in developed countries. 
Wealthy countries are more concerned about how to maintain their technological superiority and how to create or access sectors where their comparatively more expensive labor (due to higher salaries) is not a competitive hindrance. In the exporting sectors, businesses worry about how to develop new competences or enter new sectors. The problem of national competitiveness is multi-faceted and does not have one universally applicable answer.

In academic and applied research, these multiple facets give rise to distinct approaches to the study of competitiveness: studies about productivity and the cost of factors; articles about regional (Porter, 1990, 2000) or even entrepreneurial strategy (Teece, 1987; Kogut and Zander, 1993; Powell et al., 2002); analyses of institutions and national innovation systems (Nelson, 1993; Patel and Pavitt, 1994; Cantwell and Iammarino, 2000; Cantwell, 2001); and the focus on industrial clusters are a few examples. The common element is the search for a global model, a benchmark to follow.

It is important to understand what is meant by competitiveness. Although the term is widely used, its conceptualization is not evident and causes some disagreements. The fact is that the concepts of competitive strategy or competitive advantage have their ideal applications in the field of administration. In this discipline, enterprises compete with each other for market quotas, resources, workers, and leadership positions.

The ranking of the most competitive enterprises can be analyzed by means of financial or even market indicators, rates of innovation and introduction of new products, etc. Extrapolating the concept of competitiveness would mean that countries compete in world markets and are able to formulate and implement a competitive strategy. Still, it is reasonable to observe the status of state competitiveness in sectors of activity, like when we say that German enterprises have lost their competitiveness in the manufacturing of textiles, shoes, or electrical appliances (see criticisms made by Krugman, 1994).

Despite the controversies, a useful way to analyze competitiveness is by looking at structural factors, including productivity, competences, and the binomial of knowledge and innovation (Fagerberg, 1996). According to this logic, access to activities with higher aggregated value builds a national technological base that can foster the best terms of exchange for international trade. Within this context, the loss of attractiveness or competitiveness of certain sectors and 
industries means, effectively, a switch to better-remunerated activities. The essential question, however, is what needs to happen so that this change occurs and countries can offer structural conditions for their businesses to be competitive.

\subsection{THE ANALYSIS}

A country's competitiveness, or its capacity to compete in internal and external markets, is often analyzed in terms of relative costs and abundance of productive factors, and conditions of domestic rivalry and competitiveness in world markets (Porter, 1990; Krugman, 1991, 1994; Malmberg, Sölvell and Zander, 1996).

International trade indicators are frequently used in hasty analyses of national competitiveness. In essence, and in a simplified form, traditional theories posit that given that countries possess different resources and technologies, they should specialize in what they can do better relative to others, trading the products they need in international markets. Thus one could easily surmise that by looking at the composition of the balances of trade one could understand what resources are more abundant in a given country.

It is still said often, and stereotypically, that a country holding a trade surplus with others is competitive. However, national competitiveness cannot be simply evaluated by the makeup of trade flows, nor in terms of exchanges in international trade.

Many countries' export capability is based on the use of cheap labor, which is responsible for degrading living conditions and frustrates the development expectation of local populations. Other countries promote exports through exchange policies or export incentives. However, these factors are not conducive to sustainable competitiveness from the perspective of either entrepreneurial strategy or industrial policy. How then to assess national competitiveness?

An alternative analysis of national competitiveness can be made by observing the comparative advantages among countries. In this field, the works of David Ricardo (1817) outline how sectorial trade among countries is 
determined by their varying comparative advantages. Simply put, each country tends to specialize in activities where the national industry is more competitive, and thus the country will export goods in which local production is relatively more efficient and import goods whose production is comparatively less efficient.

Explanations based on Ricardian logic still persist. Nevertheless, the factors that create comparative differences among countries are radically different from those identified by Ricardo or the traditional factors of land, capital and labor. For instance, current factors of national competitiveness are based on the system of innovation and knowledge that each country has available (Kobrin, 1991; Kogut, 1991; Cantwell, 2001). In other words, innovation and knowledge are counterpoised, or at least form the main frame of reference for the relative costs of the factors of production in order to determine comparative advantage among countries.

The qualification of labor is contrasted to the quantity of labor, and natural resources are contrasted with the network of built infrastructure, which permits Holland, for instance, to be one of the world's top exporters of flowers without having a climate adequate for their production. The current perspective for analyzing national competitiveness requires more attention to the composition of exports and imports, namely their aggregated value, and the characteristics of the influxes and outflows of investment to and from abroad, by distinguishing the types of investment by their contribution to improving national competences.

In the knowledge society and economy, the goods that incorporate the highest aggregated value (and therefore the highest knowledge) are preferred. In other words, enterprises and countries in general compete to internally develop production based on elevated knowledge, as well as markets for these goods (Buckley and Casson, 1976).

Beyond the field of business, the development of a national innovation system (Kobrin, 1991; Cantwell, 2001) is important as a factor of competitiveness because it determines in which activities national enterprises can develop a comparative and competitive advantage vis-à-vis foreign enterprises. Similarly, the national innovation system influences the flows of foreign investment because it alters the relative attractiveness of certain industries in relation to others. 
When looking at a country, we can perform this analysis by examining exports and imports and R\&D expenditures in selected industries. Investment in R\&D promotes the creation of knowledge and builds or reinforces the competitiveness of these industries. On the other hand, the analysis of expenditures in R\&D allows us to make inferences about which activities and industries both enterprises and the government will bet on for the future.

Let us note another Portuguese example. It is well known that the value of Portuguese exports of high-technology products (those incorporating elevated knowledge) is far inferior to the value of corresponding imports. Portugal has the lowest level of exports of high-technology products in the European Union (Table 1). In other words, Portugal's attractiveness for the location of knowledgeintensive enterprises is low. While this situation persists, the trade deficit and national competitiveness will continue to deteriorate. In fact, the value of hightechnology exports as a percentage of the total has been decreasing. Poor competitiveness in this area thus tends to compound.

Table 1: Exports of high-technology products

\begin{tabular}{|c|c|c|c|c|c|c|}
\hline & 1990 & 1992 & 1994 & 1996 & 1998 & 2000 \\
\hline Austria & 7.90 & 8.559 & 10.214 & 10.022 & 11.399 & 13.7107 \\
\hline Belgium & 4.695 & 5.076 & 6.598 & 7.603 & 8.054 & 10,144 \\
\hline Denmark & 15.179 & 14.459 & 16.052 & 16.147 & 17.626 & 20.677 \\
\hline Finland & 7.572 & 9.327 & 13.100 & 16.304 & 21.975 & 27.334 \\
\hline France & 16.096 & 17.978 & 18.303 & 18.480 & 22.434 & 24.255 \\
\hline Germany & 11.065 & 11.778 & 12.449 & 12.786 & 14.630 & 17.710 \\
\hline Greece & 2.226 & 1.861 & 3.769 & 6.177 & 7.978 & n.d. \\
\hline Ireland & 41.057 & 36.503 & 44.818 & 46.637 & 44.141 & 47.520 \\
\hline Italy & 7.534 & 8.364 & 8.252 & 7.684 & 7.902 & 9.189 \\
\hline Holland & 16.375 & 19.163 & 22.154 & 26.509 & 29.995 & 35.446 \\
\hline Norway & 12.308 & 12.443 & 15.244 & 14.915 & 16.240 & 17.132 \\
\hline Portugal & 4.415 & 3.749 & 3.870 & 4.33 & 4.027 & n.d. \\
\hline Spain & 6.372 & 7.093 & 8.242 & 7.384 & 6.679 & 7.644 \\
\hline Sweden & 13 & 14 & 13 & 17 & 20 & 22 \\
\hline Switzerland & 12.081 & 12.737 & 12.540 & 14.787 & 16.333 & 19.307 \\
\hline UK & 23.587 & 22.950 & 25.272 & 26.366 & 28.797 & 31.999 \\
\hline USA & 33 & 33 & 31 & 31 & 33 & 34 \\
\hline Japan & 23.838 & 23.693 & 25.170 & 25.721 & 25.746 & 28.349 \\
\hline
\end{tabular}

Unit: \% of exports of manufactured goods.

Source: World Bank. World Development Indicators 2002. 


\section{FOREIGN DIRECT INVESTMENT}

Two perspectives are currently used to explain foreign direct investment (FDI). One emphasizes an enterprise's internalization of some form of specific advantage (such as knowledge, technology, or process) by virtue of imperfect markets (Buckley and Casson, 1976; Dunning, 1977, 1995, 1998; Kogut and Zander, 1992, 1993). Market imperfection can originate in multiple factors and may take the form of transaction costs (Williamson, 1985; Hennart, 1982; Rugman, 1981). In this case, enterprises make foreign direct investments to remedy an imperfect market (Hymer, 1976; Buckley and Casson, 1976). For example, when the market for knowledge of intermediate goods is imperfect, enterprises internalize transactions through investments abroad, thereby building their subsidiaries.

This approach to FDI highlights the internalization of an enterprise's own advantages, to be developed within the specific context of the domestic market and via an idiosyncratic technological path (Kogut, 1991). In other words, enterprises invest abroad to exploit their own advantages. Studies by Dunning (1981, 1988, 1995, 1998-eclectic paradigm) are interesting within this context, as they propose that enterprises become international through a conjunction of three conditions: ownership, location and internalization (OLI: cf. original). Enterprises have specific advantages, which can result from their tangible or intangible resources (ownership). The choice of a location should govern the potential for maximizing the value of the specific advantages of the enterprise, less costs (Dunning, 1981). When the transaction costs resulting from the exploration of specific advantages through the organization of market exchanges are high, the owner of the assets can internalize the foreign transactions through direct investment transactions (Buckley and Casson, 1976; Dunning, 1988). Internalization refers to the mode of entry abroad to (better) realize specific advantages in the desired location (Guisinger, 2001).

Thus, we suggest that we can use the stocks of FDI to analyze a country's technological capacity. The higher the stock of FDI, the higher the technological capacity, either because previous flows resulted in the entry of new technologies, or because the flows of foreign capital are increasingly knowledgeseeking and strategic asset-seeking (Dunning, 1993; Ferreira, 2005) and are 
applied in locations that are rich in knowledge (Jaffe, Trajtenberg and Henderson, 1993; Cantwell and Iammarino, 2000; Alcácer and Chung, 2007). An increase in the flow of FDI reveals the greater performance capacity of foreign enterprises, but it is essential to verify in which activities the investments are being made, and what the motivation is. It is no coincidence that countries like Singapore and South Korea have attracted so much FDI in recent years, given the qualification of their workforce and the quality of their infrastructures.

Thus, another perspective on FDI flows argues that an enterprise's motivation for FDI is the search for some strategic resource that the company does not have available, but which is available in the receptor country (Kogut and Zander, 1992, 1993). In some cases, the advantages can be locational, in others they can be associated with specific enterprises, and thus acquisition can be the best way to have access to these resources. In other words, it is the search for other specific advantages, and not the ownership of one's own, that determines the investments abroad (Dunning, 1995). These investments in seeking strategic resources are distinct from the traditional investments seeking to increase markets and explore specific advantages abroad (Dunning, 1993). However, the locations where the enterprises choose to make their investments also change. These investments are attracted to locations of elevated knowledge, as opposed to locations where enterprises can explore the lower costs of production factors. Therefore, it seems evident that national innovation systems attract investment in strategic assets.

One of the relevant questions in this matter now becomes that of how to evaluate the attractiveness of the locations for the FDI in view of these different motivations. One of the possible indicators, despite evident limitations, is the productivity of the labor. Productivity is an essential factor for attracting knowledge-seeking foreign investment. We can argue that productivity relies on the levels of formation and qualification of labor, but it is equally a function of the level of capitalization, and therefore the degree of development, of industry.

In Figure 1 we demonstrate this with data relative to the value aggregated per worker in a set of countries. It is well-known that in a period of 20 years the value added by Portuguese workers remained constant and low. If the value added per worker is an indicator of the competitiveness of the national industry, low levels of aggregated value reveal one with low technology and low 
incorporated knowledge. The US has one of the highest aggregated values per worker, and Ireland, Singapore, and the Republic of Korea have shown notable growth over the last twenty years. The consequence, once again, is that low levels of productivity do not attract foreign investment and only serve to demonstrate the fragilities of the national competitiveness.

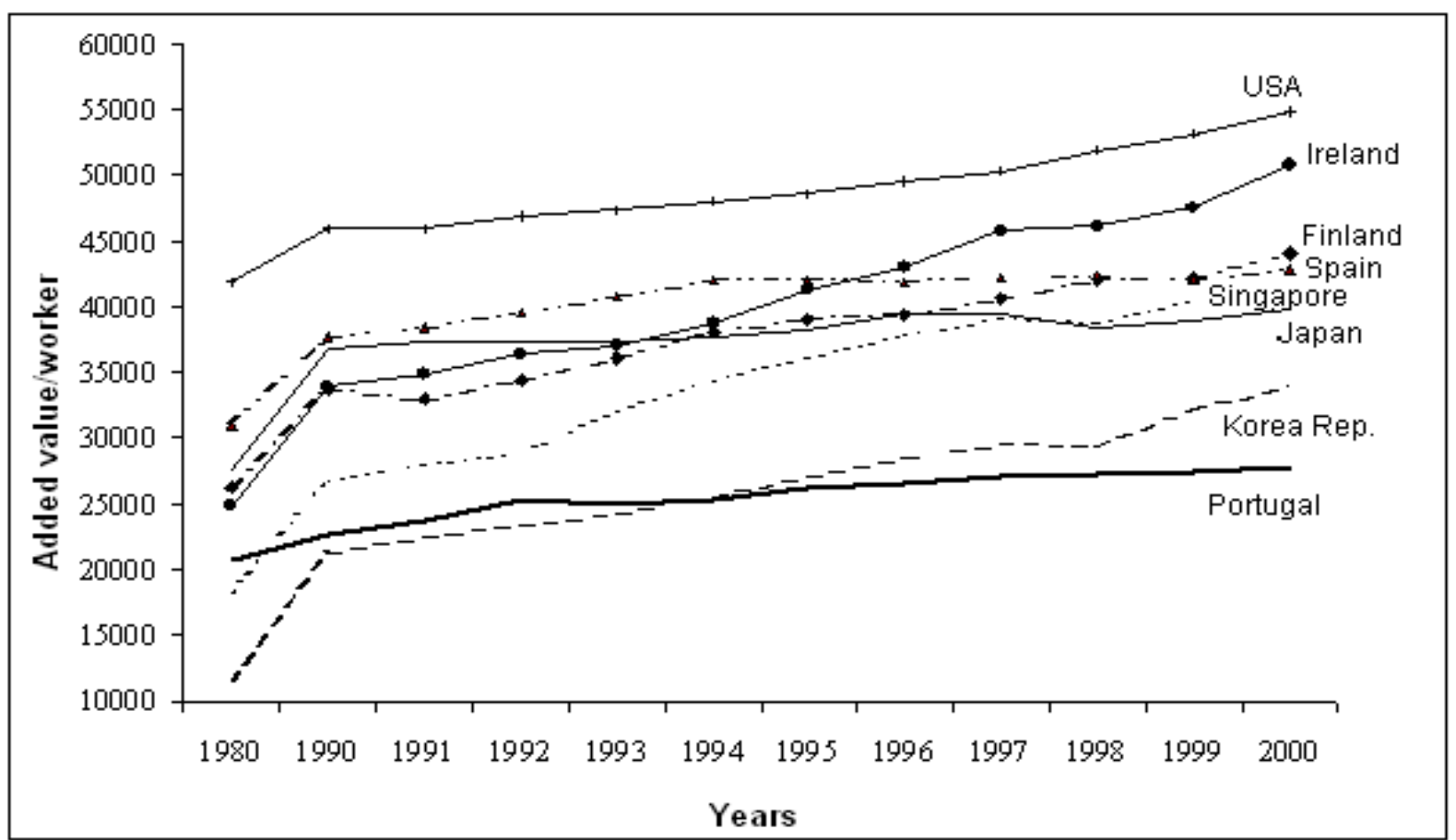

\section{Figure 1: Value added per worker}

Unit: 1990 US\$

Source: International Labor Organization, 1999.

\section{TECHNOLOGICAL PATHS AND COMPETITIVENESS}

What is the role of Research and Development (R\&D) in promoting national competitiveness? It seems reasonable to affirm that there is a positive correlation between expenditures in $R \& D$ and national competitiveness. Caves (1982) showed that expenditures in R\&D were positively correlated with FDI influxes and investments abroad, and Deardorff (1984) proved that these expenses were the highest determinant of exports. However, establishing a causal relationship seems difficult given that expenditures in R\&D can be both a determinant of exports and foreign investments and their cause. Still, it is important to highlight that countries invest in activities in which they have some kind of competitive advantage (Porter, 1990), so it is likely that the expenditures 
in $R \& D$ are channeled to areas in which the country is already reasonably competitive, which is why countries maintain some stability in the patterns of relative specialization (Kogut, 1991).

Knowledge, technologies and technological capacities accumulate at a national level in a way similar to what occurs in enterprises. Thus it is possible and frequent for a country to have a consistent strategy of knowledge accumulation, successively investing in the areas where it already has tradition: its technological path. In contrast, technological capacities in business are gradually accumulated through their own investments and joint learning with other enterprises and institutions (such as research argued that technological development follows a path based on the stock of routines, abilities, capabilities and previous know-how. Schumpeter (1934) asserted in turn that innovation can be simply based on recombining current routines and know-how. Either of these two perspectives assumes that technological development follows a path (Kogut, 1991), as opposed to the idea of technological rupture (Tushman and Anderson, 1986; Henderson and Clark, 1990).

Competitiveness, or its lack, is resistant to change. Rarely are countries able to make a technological "leap" that breaks with the path being followed. DiMaggio and Powell (1983) theorize about the adoption of similar structures and practices by enterprises. Subject to the same set of environmental variables, and using as a reference the leading companies in their sector (Haveman, 1994), enterprises develop similar offerings. Thus, the entrepreneurial variety within the national space is reduced. However, in different countries enterprises develop differentially because they are subject to another set of exogenous variables. Kogut (1991) argued that the patterns of exports and foreign investments are the manifestation of different domestic markets, but they are also the manifestation of different paths of technological accumulation. The concept of technological paths, according to which a country's technological capacity gradually accumulates, suggests why technological enterprises develop in a similar manner in each country.

There exists, when we analyze national competitiveness, an element of technological determinism, insofar as market and industry conditions, and the conditions for business creation, seem to determine their technological path (Hannan and Freeman, 1977; Porter, 1990). That is, even future technological 
advances are based on the technological stock that the enterprise already owns and on its capacity to absorb new knowledge (Cohen and Levinthal, 1990). These advances tend, therefore, to be incremental (Tushman and Anderson, 1986; Anderson and Tushman, 1990; Henderson and Clark, 1990), so they maintain the status quo. In practical terms, this means that countries tend to continue to invest in traditional industries, whereas exports reinforce the investment in exporting sectors, thus maintaining the country's international specialization. It is therefore not surprising that the specialization patterns of countries are reasonably stable.

We could argue that technological evolution does not need to be deterministic and that it can be surpassed by the immediate adoption of practices developed abroad. For instance, the re-emergence of the Japanese economy in the post-World War Two period was, at least partially, based on the imitation of technologies existing in other countries and the subsequent recombination of these technologies, but at a fraction of the cost they would have incurred if they started off from basic research. However, the fact is that other countries also imitated Japanese just-in-time practices, such as those of total quality management. Additionally, it is worth noting how it is possible to gain competitiveness by innovating incrementally-the Japanese may have imitated technology, but they later miniaturized it with enormous benefits for the sector of consumer electronics.

\section{LEARNING AND COMPETITIVENESS}

Countries can gain competitive capacity by breaking with the technological path that they follow. These ruptures are possible: the first and second industrial revolutions are examples of how they can occur. Labor division in factories and the use of steam machines and other mechanical equipment that came to replace an individual's muscular labor made the English textile industry an example of labor automation, specialization and efficiency that was adopted by multiple industrial sectors [notably for the production of automobiles and road networks, based on the principle of Taylor (1911)]. More recently, concepts like just-in-time also introduced deep alterations (innovations) in the contemporary industrial scenario (Dyer, 1996). 
To trace a new path it is necessary to acquire new knowledge. The internationalization of enterprises can be motivated by the need to learn. Enright (2000); Hendry, Brown and DeFillippi (1998); and Dunning (1993, 1995), for instance, observed how the enterprises that internationalize to zones of "excellence" (or industrial clusters) are often the type aiming to access new strategic resources (or are knowledge-seeking or strategic asset-seeking, as we previously mentioned). However, learning abroad is normally more complex than learning within the national territory, because of the various industrial paradigms that characterize different countries (Tallman, Jenkins, Henry and Pinch, 2004; Cantwell, 2001).

To learn abroad, an enterprise needs to have the capacity to absorb radically different knowledge, whereas domestic learning requires only the capacity to absorb incrementally distinct knowledges (Cohen and Levinthal, 1990; Rosenkopf and Nerkar, 2001). Learning reflects the capacity to identify, evaluate and absorb knowledge (Lane and Lubatkin, 1998; Cohen and Levinthal, 1990). Besides that, acquiring radically different knowledge requires understanding the interconnection of the entities, the productive process with customers and suppliers, and new (a) models of labor organization, (b) formats of distribution, and (c) concepts of service (Henderson and Clark, 1990; Kogut, 1991; Tallman et al., 2004). All of these, though unknown, have a strong tacit and uncoded component (Polanyi, 1966) which hinders absorption (Cohen and Levinthal, 1990; Kogut, 1991). At a national level, investments in education and learning capacity are also necessary. Countries need to have a strategy for exploiting current knowledge and technologies, while simultaneously maintaining a minimum level of investments for exploring new knowledge and an attitude of exploration and learning (March, 1991; Kogut, 1991). Moreover, it is worth noting that countries do not need to innovate in all areas, but rather focus on that which has the potential to generate a long-term sustainable competitive advantage.

A simplistic way to analyze a country's endowment of knowledge and the commercial attractiveness of this knowledge is by observing financial flows in the form of royalties (Table 2). Higher influxes reveal higher innovative capacity, while lower influxes manifest weak innovation capacity, at least in that which is technologically tradable. More technologically developed countries can exploit 
their knowledge without an inevitable need for their enterprises to internationalize, because the benefits of knowledge can arise in the form of royalties and fees for its use. Data on Table 2 are therefore not surprising when we notice that countries like the US, the UK, Japan, Germany and Holland benefit from elevated influxes, in contrast with countries like Greece and Portugal.

Table 2: Income in royalties and license fees

\begin{tabular}{l|r|r|r|r}
\hline & $\mathbf{1 9 8 0}$ & $\mathbf{1 9 9 0}$ & $\mathbf{2 0 0 0}$ & SuM 1990-2000 \\
\hline Austria & 36.1 & 90.9 & 161.6 & 1421.6 \\
\hline Belgium & 184.4 & 682.0 & 780.3 & 8446.9 \\
\hline Finland & 3.5 & 50.5 & 912.2 & 2216.3 \\
\hline France & 495.7 & 1294.7 & 2310.2 & 19601.2 \\
\hline Germany & 608.4 & 1987.0 & 2821.5 & 29381.1 \\
\hline Greece & 0.0 & 0.0 & 5.4 & 31.2 \\
\hline Ireland & 0.0 & 38.0 & 504.0 & 1799.0 \\
\hline Italy & 95.7 & 1040.0 & 563.3 & 5022.6 \\
\hline Japan & 350.0 & 2866.0 & 10227.2 & 63634.3 \\
\hline Holland & 418.3 & 1085.7 & 2171.5 & 22440.7 \\
\hline Norway & 90.3 & 133.0 & 131.0 & 1248.5 \\
\hline Portugal & 3.6 & 13.5 & 29.5 & 269.1 \\
\hline Spain & 36.2 & 90.1 & 421.1 & 2273.2 \\
\hline Sweden & 89.9 & 563.0 & 1274.8 & 10465.5 \\
\hline Switzerland & 0.0 & $\mathrm{n} . \mathrm{d}$ & $\mathrm{n} . \mathrm{d}$ & $\mathrm{n} . \mathrm{d}$ \\
\hline UK & 1135.1 & 3055.0 & 7538.0 & 63067.8 \\
\hline US & 7080.0 & 16640.0 & 38030.0 & 309770.0 \\
\hline
\end{tabular}

Unit: million dollars at BoP prices

Source: World Bank, World Development Indicators 2002.

\subsection{PROMOTING LEARNING}

Recent industrial policies have, in various ways, acknowledged the benefits of leveraging the effects of knowledge spillovers. These policies can be implemented in two essential ways, first by fostering foreign investments in the national territory. However, this support can have various objectives. Besides seeking to reduce the dependence on employability in industrial sectors, the promotion of FDI is aimed at introducing new knowledge and technology, possibly radically new-i.e. the prospect of a rupture with the current status 
quo-which have the potential to create new industrial clusters ${ }^{2}$. The idea is that learning can be fostered by exposing enterprises (universities, technological centers, etc.) to foreign competition.

A second way of promoting learning is based on fostering the establishment of partnerships among businesses and their integration into research or manufacturing networks. To advance partnerships with customers, suppliers and competitors aimed at enhancing the potential of technological development, enterprises need to have reached the thresholds of development and technological receptivity, without which no learning will occur. In other words, in order to learn, enterprises need to maintain the capacity to absorb new knowledges (Cohen and Levinthal, 1990).

The participation in relational networks and partnerships with customers, suppliers and/or competitors enriches the stock, or capital, of knowledge and technologies that the enterprise can access (Gulati, 1998, 1999). In synthesis, these partnerships increase the stock of technologies that the enterprise can access and, consequently, enhance its capacity to learn, or absorb, new technologies (Cohen and Levinthal, 1990). Partnerships with foreign enterprises-and therefore with different paradigms-contain, predictably, the absorption of elements of radical technology. Thus, these partnerships with foreign enterprises bring the opportunity for more learning because they expose the enterprise to technologies that are idiosyncratic to the innovation system of the country of origin of the foreign enterprise. Still, it is important to note that partnerships with other national enterprises also enable learning, most likely through the recombination of existing knowledge (Schumpeter, 1934).

Learning can allow breaking with technological paths that are inadequate for contemporary markets. It is our suggestion that breaking with previous technological paths requires the entry into the market of foreign enterprise, which introduces to the local industrial structure new processes, paradigms, technologies, models of labor organization, and distinct portfolios of products and markets. Stiglitz (1987) argued that the conditions of local learning and the costs of technological change force a country to remain on a determined long-

2 Examples exist of world-renowned clusters in various industries and countries, such as in Indonesia (electronics), in the US (various biotechnological clusters), in Korea (automobile, textiles and electronics), in Spain (metalworking), in Japan (state-of-the art technology and automobile), etc. (Markusen, 1996). 
term technological path. That is, a country that is efficient in the use of obsolete technology, engaged in a production routine, or poorly qualified can find itself stuck with the use of suboptimal technologies that limit access to new technological "vacancies." Therefore, technological development has an eminently local origin, namely learning within the scope of enterprises, with its attendant specific technological paths.

The effects of local learning can account for the existence of locally based industrial clusters (Markusen, 1996; Cooke, 2001). Being localized, enterprises can benefit from learning that consists, essentially, of technological spillovers from dominant enterprises, or innovations for follower enterprises (Markusen, 1996; Maskell, 2001). It is also clear that these industries are characterized by enterprises which are to a great extent isomorphic (that is, which follow the same forms of production, product portfolio, and target markets). The evident result is that enterprises, and perhaps the entire national industry, stays captive to a technological path that sustains the current status quo, in which enterprises specialize in their central competences (Prahalad and Hamel, 1990) regardless of market requirements. These competences are based on doing what they know best-reproducing routines (Nelson and Winter, 1982)-with weak potential to generate more radical technological developments (Henderson and Clark, 1990).

In short, it seems reasonable to affirm, in accordance with Stiglitz (1987), that the entry of foreign enterprises has the potential to alter the learning pattern while imposing new requirements on existing businesses and institutions. The entry of enterprises from outside a region alters the current technological capital and exposes local enterprises to new knowledge. Presence in external markets, strategic partnerships (strategic alliances or joint ventures), participation in innovation and research networks, or competition in the domestic market with enterprises that incorporate these technologies, all facilitate the acquisition of knowledge.

\section{INSTITUTIONS AND COMPETITIVENESS}

The development of competitive capacity with regard to advances in knowledge and technologies occurs within the current institutional context. Domestic institutions have been neglected in technological development and innovation policies. However, domestic institutions play an essential role in 
technological and industrial development. An evident function of institutions is R\&D. Some institutions favor learning or the application of basic sciences to economic activities, whereas others, like those promoting internationalization and international trade, take on a distinct function: fostering the exploration of current technological capacities and the exposure to new knowledge.

A third group of institutions promotes the entry of radical technologies (here understood as substantially different from current ones) aimed at provoking "leaps" in national technological development. Within this group are those that support the education of master's and doctoral students abroad. The idea is that these doctorates introduce new concepts, models and technologies that do not yet exist on the national scene. Thus, knowledge-fostering policies can value doctorates earned abroad, inter-institutional post-doctorate mobility, and the mobility of students within the country.

It is less advantageous for students to have their entire formation in the same institution-to a point where a number of professors have never left the school where they studied. A fourth group of institutions, like the patent office, aims at protecting industrial intellectual property, with a view to ensure the maintenance of certain incentives and protection to $R \& D$ expenditures. A final group of institutions should promote participation in networks of an industrial nature, such as strategic alliances and joint ventures (or other models based on joining capital, knowledge and technologies) with an entrepreneurial intent (i.e. commercial, as opposed to research).

The biggest challenge in the current context seems to be defining the agent that promotes these institutions. In fact, the burden has fallen on the State, a fact that in itself is distinct from what occurs in the US, for instance, where business assumes a key role in the financial and human capital involved (such as the financial support provided to universities). However, this burden has to also be borne by enterprises, seeing as they also benefit from technological advances. The difficulty, however, is that in many countries knowledge is seen as a public good, which not everyone uses, which many despise, and which no-one wishes to pay for. Therefore, whereas in some countries business makes the most investments in R\&D [Belgium (66\%), Denmark (58\%), Ireland (69\%), the US, (67\%) and Japan (72\%)], in other countries the responsibility for R\&D is borne by the State [Spain (41\%), Greece (49\%), Portugal (70\%)] (data from the 
OECD, 2001: Main indicators of science and technology). It is evident that the first group of countries is considerably more competitive, and wealthier, than the second.

\section{DISCUSSION AND FINAL REMARKS}

In this article we discussed national competitiveness with a special focus on knowledge. The focus is on direct foreign investment, whether input or output, as a vehicle for accessing new knowledge, new technologies and innovations. It is fundamentally a vehicle for learning, complementing the role of other institutions, namely domestic ones. The reality for many countries of intermediate development is that they suffer from low levels of productivity that prevents their standards of living from catching up with more developed countries. The current reality is that those developing countries that have traditionally established the basis of their competitive capacity on aspects like relatively low labor costs can no longer face the competition emerging from, for example, southeast Asia. More developed countries also have to cope with threats to their competitive capacity. Within this context, countries in general seem to be developing public policies that promote innovative sectors, ones supposedly more knowledge-intensive (like energy and the environment), while ignoring more traditional sectors and investing more in the qualification of the population through support for R\&D and education/formation.

The objective of this article is to discuss-perhaps in a speculative manner, given that we do not conduct empirical tests of hypotheses-and register the importance of understanding national competitiveness framed in knowledge and innovation. From the standpoint of public policies, it is evident that our suggestion is that governments need to act to take down barriers to new learning and innovation as a way to increase both productivity and economic growth. On the other hand, it is important to understand the role of institutions and foreign direct investment in the introduction of new knowledge that will permit the leveraging of the stock of knowledge already available.

No country can consciously aim to achieve an absolute advantage in all activities (Porter, 1990; Kogut, 1991; Dunning, 1995). Also, not all countries can expect to achieve leadership in certain sectors of activity (Kogut, 1991). At the 
root of national competitiveness seems to be a country's capacity to generate new knowledge and innovation and to alter its technological paths, even in an incremental manner, from variations in markets. The reality, however, is that not all countries are innovative (Dunning, 1995). In this article we discussed the core question of national competitive capacity framed by knowledge, learning and institutions. This discussion draws on indicators of the flow of direct investment to and from abroad, international trade, endowment and quality of human resources, and innovation systems.

What each country can aspire to have is an entrepreneurial and institutional system that allows it to absorb the spillover from technological innovations generated by other countries. One of the most relevant aspects is therefore the capacity to learn, to absorb external knowledge and apply them to marketable productions. The endowment, or stock, of national knowledge is crucial, but requires that we understand it within the context of the technological path followed. It would thus seem obvious that in terms of innovation policy this requires some volume of investment in learning and cutting-edge $R \& D$, but does not warrant a strategy that scatters scarce financial resources in research (basic or applied) in all areas of activity.

Countries without a clear strategy of industrial and technological development cannot reasonably expect substantial FDI influxes. First, because a good portion of the FDI flow seeks out poles of knowledge excellence. Without them, the only attraction would be the size of the market or the search for cheaper productive factors. Many countries are only attractive from the point of view of exploitation of lower factor costs, especially labor, and for the production of goods requiring little knowledge. Second, enterprises from countries which do not innovate fail to develop specific advantages that can translate into an advantage abroad, for example. These countries can neither export nor expand through FDIs.

Investments in learning, which enable technological development by integrating networks and just-in-time delivery strategies, can be more or less dispersed on the basis of the generality of economic activities. These are lowcost investments and raise capacities within the R\&D scope. These investments can consist of academic scholarships and post-doctorates, and especially support for the incorporation of networks with nodes, through which investments allow 
the creation of standards of excellence. The predictable result is the enrichment of the national technological base, the alteration of the national technological specialization pattern in the medium term, the increase in the added value of labor, and flows of foreign direct investment to qualified activities.

For example, while some investments should be channeled to pure research, the remaining investments should be dedicated to learning (i.e. education) that facilitates the absorption of the knowledge developed abroad. This is a fundamental distinction in terms of public policy: Is it reasonable to expect that Portugal can take on a leadership position in biotechnology that justifies the enormous investments that have been made? Moreover, investments in learning capacity may be related to economic activities in which the country already maintains superior quality, and those in areas with endogenous resources that can achieve a high aggregated value added through the incorporation of knowledge. In essence, this is an analysis of the competitive advantages of nations, as posited by Porter (1990).

\section{REFERENCES}

Alcácer, J.; Chung, W. (2007). Location strategy and knowledge spillovers. Management Science, 53 (5), 760-776.

Anderson, P.; Tushman, M. (1990). Technological discontinuities and dominant designs: A cyclical model of technological change, Administrative Science Quarterly, 35 (4), 604-633.

Buckley, P.; Casson, M. (1976), The future of the multinational enterprise, Londres: Macmillan Press.

Cantwell, J. (2001). Innovation and information technology in MNE. In T. Brewer (ed.). The Oxford handbook of international business. Oxford: Oxford University Press.

Cantwell, J.; Iammarino, S. (2000). Multinational corporations and the location of technological innovation in the UK regions. Regional Studies, 34 (4), 317-332.

Caves, R. (1982). Economic analysis and multinational enterprises. Cambridge: Cambridge University Press.

Chen, H.; Chen, T.J. (1998). Network linkages and location choices in foreign direct investment. Journal of International Business Studies, 29 (3), 445-468. 
Cohen, W.; Levinthal, D. (1990). Absorptive capacity: A new perspective on learning and innovation. Administrative Science Quarterly, 35 (1), 128-152.

Cooke, P. (2001). Regional innovation systems, clusters, and the knowledge economy. Industrial and Corporate Change, 10 (4), 945-974.

Deardorff, A. (1984). Testing trade theories and predicting trade flows. In R. Jones \& P. Kenen (eds.). Handbook of International Economics. Amsterdam: Elsevier Science Pub.

DiMaggio, P.; Powell, W. (1983). The iron cage revisited: Institutional isomorphism and collective rationalityin organizational fields. American Sociological Review, 48, 147-160.

Dunning, J. (1977). The location of economic activity and the multinational enterprise: A search for an eclectic approach. In B. Ohlin, P. Hesselborn \& P. Wilkman (eds). The international allocation of economic activity. London: Macmillan, 359-418.

Dunning, J. (1981). International production and the multinational enterprise, Londres: Allen \& Unwin.

Dunning, J. (1988, spring). The eclectic paradigm of international production: A restatement and some possible extensions. Journal of International Business Studies, 1-31.

Dunning, J. (1993). Multinational enterprises and the global economy. AddisonWesley Publishing Company.

Dunning, J. (1995). Reappraising the eclectic paradigm in an age of alliance capitalism. Journal of International Business Studies, 26 (3), 461-491.

Dyer, J. (1996). Specialized supplier networks as a source of competitive advantage: Evidence from the auto industry. Strategic Management Journal, $17(4), 271-292$.

Enright, M. (2000). Regional clusters and multinational enterprises: independence, dependence, or interdependence? International Studies of Management \& Organizations, 30 (2), 114-138.

Fagerberg, J. (1996). Technology and competitiveness. Oxford Review of Economic Policy, 12 (3), 39-51.

FCT. (2003). Agenda de C\&T 2003. Fundação Para a Ciência e a Tecnologia, Ministério da Ciência e do Ensino Superior, Lisboa, Portugal.

Ferreira, M.P. (2005). Building and leveraging knowledge capabilities through cross border acquisitions: the effect of the MNC's capabilities and knowledge strategy on the degree of equity ownership acquired. Tese de Doutorado, University of Utah, Utah, Estados Unidos. 
Ferreira, M.P. \& Tallman, S. (2005). Building and leveraging knowledge capabilities through cross-border acquisitions. Academy of Management, Hawaii, EUA.

Ferreira, M.P; Li, S.; Lopes, M. \& Serra, F. (2007). Cross-border acquisitions of foreign firms in Portugal and of Portuguese firms abroad: exploration and exploitation through acquisitions. Economia Global e Gestão, 12 (1), 125-147.

Grant, R. (1991). Porter's 'Competitive advantage of nations: an assessment. Strategic Management Journal, 12, 535-548.

Grant, R. (1996). Toward a knowledge-based theory of the firm. Strategic Management Journal, 17, 109-122.

Guisinger, S. (2001). From OLI to OLMA: Incorporating higher levels of environmental ad structural complexity into the eclectic paradigm. International Journal of the Economics of Business, 8 (2), 257-272.

Gulati, R. (1998). Alliances and networks. Strategic Management Journal, 19 (4), 293-317.

Gulati, R. (1999). Network location and learning: the influence of network resources and firm capabilities on alliance formation. Strategic Management Journal, 20 (5), 397-420.

Hannan, M.; Freeman, J. (1977). The population ecology of organizations. American Journal of Sociology, 82, 929-964.

Haveman, H. (1994). Follow the leader: mimetic isomorphism and entry into new markets. Administrative Science Quarterly, 38, 593-627.

Henderson, R.; Clark, K. (1990). The reconfiguration of existing product technologies and the failure of established firms. Administrative Science Quarterly, 35, 9-30.

Hendry, C.; Brown, J. \& DeFillipi, R. (1998). Regional clustering of high technology-based firms: opto-electronics in three countries. Regional Studies, $34(2), 129-144$.

Hennart, J.F. (1982). A theory of multinational enterprise. University of Michigan Press: Ann Arbor.

Hymer, S. (1976). The international operations of national firms: a study of direct foreign investment, Cambridge, Mass: MIT Press.

ILO (1999). Key indicators of the labour market. Geneva: International Labour Office.

Jaffe, A.; Trajtenberg, M.; Henderson, R. (1993). Geographic localization of knowledge spillovers as evidenced by patent citations. The Quarterly Journal of Economics, 108 (3), 577-598. 
Kobrin, S. (1991). An empirical analysis of the determinants of global integration. Strategic Management Journal, 12, 17-31.

Kogut, B. (1991). Country capabilities and the permeability of borders, Strategic Management Journal, 12, 33-47.

Kogut, B.; Zander, U. (1992). Knowledge of the firm, combinative capabilities, and the replication of technology. Organization Science, 3, 383-397.

Kogut, B.; Zander, U. (1993). Knowledge of the firm and evolutionary theory of the multinational corporation. Journal of International Business Studies, Fourth quarter, 625-645.

Krugman, P. (1991). Geography and trade. Cambridge, Mass.: MIT Press.

Krugman, P. (1994). Competitiveness: a dangerous obsession. Foreign Affairs, $73(2), 28-44$.

Krugman, P. (1994). Complex landscapes in economic geography. American Economic Review, 84, 2, 412-416.

Krugman, P. (1996). Making sense of the competitiveness debate. Oxford Review of Economic Policy, 12 (3), 17-25.

Lane, P. \& Lubatkin, M. (1998). Relative absorptive capacity and interorganizational learning. Strategic Management Journal, 19 (5), 461-477.

Levinthal, D. \& March, J. (1993). The myopia of learning. Strategic Management Journal, 14, 95-112.

Li, D.; Ferreira, M. P.; Serra, F. (2009). Technology transfer within MNEs: intersubsidiary competition and cooperation. Revista de Administração e Inovação, 6, 139-158.

Maddison, A. (1982). Phases of capitalist development. Oxford: Oxford University Press.

Malmberg, A.; Sölvell, Ö. \& Zander, I. (1996). Spatial clustering, local accumulation of knowledge and firm competitiveness. Geografiska Annaler, 78, (B2), 85-97.

March, J. (1991). Exploration and exploitation in organizational learning, Organization Science, 2 (1), 71-87.

Markusen, A. (1996). Sticky places in slippery space: a typology of industrial districts. Economic Geography, 72 (3), 293-313.

Maskell, P. (2001). Towards a knowledge-based theory of the geographical cluster. Industrial and Corporate Change, 10 (4), 921-943.

Nelson, R. (ed.) (1993). National innovation systems. A comparative analysis, Oxford: Oxford University Press. 
Nelson, R. \& Winter, S. (1982). An evolutionary theory of economic change. Cambridge, MA: Harvard University Press.

OCDE (2001). Main indicators of science and technology. Paris: OECD.

Patel, P. \& Pavitt, K. (1994). The nature and economic importance of national innovation systems. STI Review, (14), Paris: OECD.

Polanyi, M. (1966). The tacit dimension. Garden City, NY: Doubleday.

Porter, M. (1990). The Competitive advantage of nations. New York: Free Press.

Porter, M. (2000). Location, competition and economic development: local clusters in a global economy. Economic Development Quarterly, 14 (4), 15-3.

Powell, W.; Koput, K.; Bowie, J. \& Smith-Doerr, L. (2002). The spatial clustering of science and capital: accounting for Biotech firm-venture capital relationships. Regional Studies, 36 (3), 291-305.

Prahalad, C.K. \& Hamel, G. (1990, maio/junho). The core competence of the corporation. Harvard Business Review, 79-91.

Ricardo, D. (1817). On the principles of political economy and taxation. London: John Murray.

Rosenkopf, L. \& Nerkar, A. (2001). Beyond local search: boundary-spanning, exploration, and impact in the optical disk industry. Strategic Management Journal, 22, 287-306.

Rugman, A. (1981). Inside the multinationals: The economics of internal markets. London: Croom Helm.

Schumpeter, J. (1934). The theory of economic development. Cambridge, MA: Harvard University Press.

Schumpeter, J. (1947). Capitalism, Socialism, and Democracy. New York, London: Harper \& brothers.

Stiglitz, J. (1987). Learning to learn, localized learning and technological progress. In P. Dasgupta \& P. Stonema (eds.). Economic policy and technological performance. New York: Cambridge University Press.

Strang, D. \& Soule, S. (1998). Diffusion in organizations and social movements: From hybrid corn to poison pills. Annual Review of Sociology, 24. 265-290.

Tallman, S.; Jenkins, M.; Henry, N. \& Pinch, S. (2004). Knowledge, clusters and competitive advantage. Academy of Management Review, 29 (2), 258-271.

Taylor, F. (1911). The principles of scientific management. New York: Harper Bros.

Teece, D. (1987). Profiting from technological innovation: implications for integration, collaboration, licensing and public policy. In D. Teece (ed.). The competitive challenge-strategies for industrial innovation and renewal, Cambridge, MA: Ballinger. 
Tushman, M. \& Anderson, P. (1986). Technological discontinuities and organizational environments. Administrative Science Quarterly, 31 (3), 439-465.

WDI. (2002). World Development Indicators 2002. World Bank.

Williamson, O. (1985). The Economic institutions of Capitalism. New York: Free Press. 